\title{
APPLICATION VALIDITY OF THE TECHNOLOGICAL PROCEDURE FOR MAKING SPIRAL DRILL-BIT GROOVES
}

\author{
OVREDNOTENJE UPORABNOSTI TEHNOLOŠKEGA POSTOPKA \\ IZDELAVE SPIRALNIH SVEDROV
}

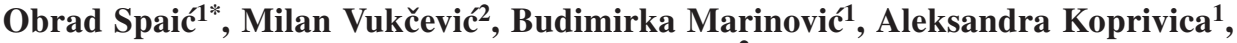 \\ Janko Jovanović ${ }^{2}$ \\ ${ }^{1}$ University of East Sarajevo, Faculty of Production and Management Trebinje, Stepe Stepanovića bb, Trebinje 89101, Bosnia and Herzegovina \\ 2 University of Montenegro, Faculty of Mechanical Engineering, Podgorica 81000, Montenegro \\ Prejem rokopisa - received: 2020-05-07; sprejem za objavo - accepted for publication: 2020-09-17
}

doi:10.17222/mit.2020.071

The current world trends and the global market require production organizations to increase the quality while reducing the costs of their products. In most cases, traditional production technologies of spiral drill bits (SD) cannot meet these expectations, as they most often fulfil only one of the set requirements. Thus, the cost of a SD produced with the rolling technology is low, but its quality is also much lower than that of the drills produced with the grinding technology whose cost is also much higher. The grooves of the SDs produced with our new technological method have advantages over the grooves produced with the rolling technology or grinding technology, and the savings in the material and grinding wheel are higher compared to the SDs produced with the grinding technology. This paper presents an analysis of the application of this new technological process for producing SD grooves.

Keywords: drilling, grinding, rolling, new technologies

Trenutni svetovni trendi na globalnem trgu zahtevajo od proizvodnih podjetij stalno izboljševanje kakovosti njihovih izdelkov ob istočasnem zmanjševanju stroškov. V večini primerov tradicionalne tehnologije proizvodnje oz. izdelave spiralnih svedrov (SD) ne morejo izpolnjevati teh zahtev in lahko pogosto izpolnijo le enega od zahtevanih pogojev. Stroški izdelave spiralnih svedrov, izdelanih s tehnologijo valjanja so nižji in tudi njihova kvaliteta je slabša od tistih, ki so izdelani s precej dražjo tehnologijo brušenja. Izdelava trna in brazd na spiralnih svedrih z novim tehnološkim postopkom omogoča zmanjšanje porabe materiala v primerjavi z obstoječima tehnologijama izdelave $\mathrm{z}$ valjanjem in brušenjem. V pričujočem članku avtorji opisujejo, analizirajo in ocenjujejo nov tehnološki postopek izdelave spiralnih svedrov.

Ključne besede: rezkanje, brušenje, valjanje, nove tehnologije

\section{INTRODUCTION}

One of the most commonly used cutting tools is a spiral drill bit (SD), which can be manufactured using technologies such as: forging, milling, grinding, rolling and extrusion. ${ }^{1-3}$ The geometry of SDs is more complex than the geometry of other cutting tools, so it takes a lot of time, engineering knowledge and research to construct and manufacture them. ${ }^{4}$

Therefore, the researchers in this field tried, based on the appropriate input parameters, to develop software solutions for an automatic generation of 3D models. Thus, in 2006, Vijayaraghavan ${ }^{5}$ developed a tool in SolidWorks 2003 for an automatic generation of 3D models of SDs, based on the production parameters. In the production of conventional SDs with two spiral grooves, the two basic operations are the fabrication of the spiral groove and grinding the front surface, which defines the geometric parameters of a SD. Parameters such as the top angle and core thickness imply the functions of a SD. In 2012, J. Jovanović et al. ${ }^{6}$ developed software for a profile generation of SD-groove tools depending on the nominal diam-

*Corresponding author's e-mail:

obradspaic59@gmail.com, obrad.spaic@fpm.ues.rs.ba (Obrad Spaić) eter of the SD, core diameter, angle of rise and top angle, provided that the main cutting edge is a straight line and the width values of the key and groove are in a ratio of $1: 1$.

Production technologies of SDs do not satisfy the criteria of quality and costs equally. So, for example, the rolling technology results in material savings and better strength properties. ${ }^{1}$ This means that the cost is lower, but the quality is also much lower than that of the drill bits made with the grinding technology, whose cost is much higher.

When analyzing grinding and rolling, from the aspect of their advantages and disadvantages, we decided to design a new technological process for producing the groove of a $\mathrm{SD}$, based on the advantages of these two technologies.

This new technological process involves a combination of the rolling technology as the initial operation, and the grinding technology as the finishing operation. With the groove thus produced, the SD retains all the advantages of the rolling technology (good mechanical properties due to the continuous flow of material fibers, considerable material savings and reduced main fabrication time) and grinding technology (greatly improved geo- 
metric accuracy and quality of the machined surface and reduced cutting resistance).

This paper analyzes the justification for the application of the new technological process for the production of SD grooves in relation to rolling and grinding as the most commonly used technologies for producing SD grooves so far.

\section{TECHNOLOGIES FOR PRODUCING SD GROOVES}

SD-producing technologies are named after the method of making grooves: forging, milling, grinding and extrusion. ${ }^{1,6-11}$

\subsection{Grinding technology}

The first steps in the production of the spiral groove on a drill bit by grinding were made in 1931 on drill bits with small diameters (up to $\varnothing 3.0 \mathrm{~mm}$ ), but the technology began to be applied in the regular production of tools only in the late 1950s.

The development of deep grinding (full grinding or single grinding) made it possible to produce spiral grooves on larger drill bits, see Figure 1.

The main advantages of producing the spiral groove on a drill bit with the grinding technology are significantly improved surface quality and accuracy of shapes and dimensions.

\subsection{Rolling technology}

The rolling process of SD manufacturing, illustrated in Figure 2, was introduced into industrial production in the 1960s and had a lot of advantages in the serial and mass production. The productivity of the SD production by rolling increased by 15-20 times in comparison to the milling technology, while the material saving went up to

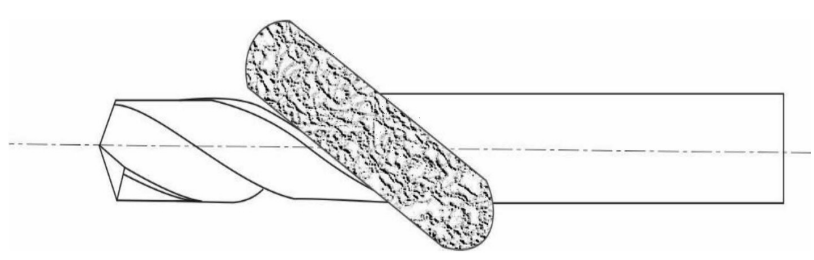

Figure 1: Production of SD grooves by grinding

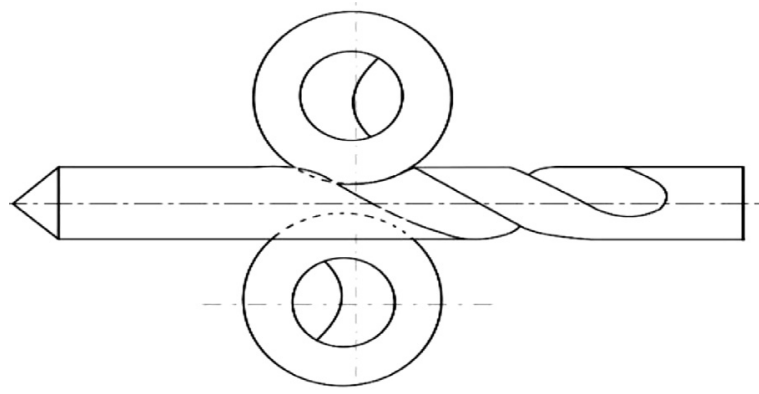

Figure 2: Production of SD by rolling
$30 \%$. Namely, with this technology, there is no loss of material in the formation of grooves because it is transformed into the drill bit during the rolling process.

The advantages of producing the spiral groove of a drill bit with the rolling technology are increased material savings, good mechanical properties of the drill due to the continuous flow of fibers of the material and the deviation of the groove-profile dimensions.

\section{ANALYSIS OF THE SD-GROOVE PRODUCTION WITH THE GRINDING AND ROLLING TECHNOLOGIES}

An economic analysis of the production of SD grooves with the rolling and grinding technologies was carried out, considering two aspects:

- saving the basic material and

- grinding-wheel savings.

The analysis was carried out on DIN 338 drill bits with nominal diameters of $(\varnothing 12, \varnothing 15$ and $\varnothing 20) \mathrm{mm}$, made of high-speed steel (EN standard HS 6-5-2, DIN S 6-5-2, W. Nr. 1.3343), which is most commonly used for the production of SDs. A higher carbon content affects the formation of carbides. ${ }^{12}$

In accordance with the SD producer's technological charts, the dimensions and weights of the raw parts for the SD nominal diameters of $\varnothing 12, \varnothing 15$ and $\varnothing 20 \mathrm{~mm}$, used for rolling and grinding are shown in Table 1.

Table 1: Dimensions and weights of raw parts for SD rolling and grinding

\begin{tabular}{|l|l|c|c|c|}
\hline \multicolumn{2}{|l|}{ Nominal diameter of the SD (mm) } & $\varnothing 12$ & $\varnothing 15$ & $\varnothing 20$ \\
\hline \multicolumn{2}{|l|}{ Total length of the SD (mm) } & 151 & 169 & 205 \\
\hline \multicolumn{2}{|l|}{ Length of the handle (mm) } & 49 & 54 & 64 \\
\hline $\begin{array}{l}\text { Dimensions of the } \\
\text { raw part }\end{array}$ & $\begin{array}{l}\text { Nominal di- } \\
\text { ameter (mm) }\end{array}$ & 12.3 & 15.3 & 20.3 \\
\hline \multirow{2}{*}{ Length (mm) } & Rolling & 104 & 114 & 143 \\
\cline { 2 - 5 } & Grinding & 151 & 169 & 205 \\
\hline \multirow{2}{*}{$\begin{array}{l}\text { Weight of the raw } \\
\text { part (g/piece) }\end{array}$} & Rolling & 100.84 & 171.03 & 377.67 \\
\cline { 2 - 5 } & Grinding & 146.41 & 253.54 & 541.41 \\
\hline $\begin{array}{l}\text { Difference in } \\
\text { weight }\end{array}$ & $(\mathrm{g})$ & 45.57 & 82.51 & 163.74 \\
\cline { 2 - 5 } & $(\%)$ & 31.12 & 32.54 & 30.24 \\
\hline
\end{tabular}

From the data presented in Table 1, it can be concluded that the material savings in the production of SD grooves by rolling are significant, amounting to about $30 \%$. The conducted analysis confirms the economic justification for designing a new technological process for the production of SD grooves.

\section{ANALYSIS OF THE NEW TECHNOLOGICAL PROCEDURE OF PRODUCING SD GROOVES}

With the new technological process, rolling is performed as the pre-operation with a grinding additive, followed by heat treatment and a grinding operation as the finishing operation. 
The rolling process allows us to achieve good mechanical properties due to the continuity of the fiber flow, considerable material savings and reduced fabrication time, while the grinding process ensures that the SD exhibits, in addition to the aforementioned characteristics, features such as significantly improved dimensional accuracy and surface quality.

It is important to note that the combination of technological processes caused, in addition to the material savings and due to a small grinding additive, significant savings in the consumption of the grinding wheel, compared to the grinding technology.

The economic analysis of the new technological process for producing SD grooves was also carried out on SD DIN 338 with nominal diameters of $\varnothing 12, \varnothing 15$ and $\varnothing 20 \mathrm{~mm}$, made of the HS 6-5-2 high-speed steel, with respect to material and grinding-wheel savings.

\subsection{Economic analysis of the new technological pro- cess for producing $S D$ grooves with respect to mate- rial savings}

SDs are produced with the new technology from a raw part with the same nominal diameter as with the previously analyzed technologies, Table $\mathbf{1}$.

However, since the new technological process of producing SD grooves includes a rolling operation with a grinding additive $\left(A_{2}\right)$, Figure 3 , a smaller volume of the material is extruded from the spiral grooves into the body of the SD.

As the length of the formed spiral part of the extruded material is smaller, the length of the raw part must be longer than the length of the groove raw part of the SD made by rolling by length $x$. In Figure 3, the groove surface in the cross-section of the SD after the rolling operation is denoted by $A_{1}$ and after the grinding opera-

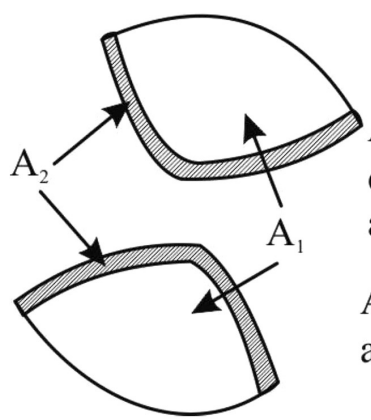

$\mathrm{A}_{1}$ - the groove surface in cross section SD after rolling operation

$\mathrm{A}_{2}$ - the surface of grinding addition in cross section SD

Figure 3: Cross-section surfaces of the SD tion by $A_{1}+A_{2}$. The difference between the length of the raw part used for the new method of producing SD grooves and the length of the groove raw part of the SD made by rolling, that is, the length of the SD body made from the volume of the grinding additive can be obtained from the equality of the volume of the grinding extension and the volume of the SD body formed with the grinding additive:

$$
V_{\mathrm{ga}}=V_{\mathrm{ba}}
$$

where

$V_{\mathrm{ga}}$ - the volume of the grinding additive and

$V_{\mathrm{ba}}$ - the volume of the SD body made with the grinding additive.

Acknowledging that:

$$
V_{\mathrm{ga}}=A_{2} \cdot l_{\mathrm{s}} \text { and } V_{\mathrm{ba}}=A_{\mathrm{t}} \cdot x
$$

where

$A_{2}$ - the surface of the cross-section of the grinding additive,

$l_{\mathrm{s}}$ - the length of the raw part where groove rolling is performed,

$A_{\mathrm{t}}=A-A_{1}-$ the surface of the cross-section of the SD body,

$A$ - the surface of the cross-section of the raw part and $A_{1}$ - the surface of the cross-section of 2 grooves with the grinding additive,

$x$ - the length of the SD body made with the grinding additive.

Thus, we obtain:

$$
x=\frac{V_{\mathrm{ga}}}{A_{\mathrm{t}}}=\frac{A_{2} \cdot l_{\mathrm{s}}}{A-A_{1}}
$$

The cross-sectional surface of the grinding additive $A_{2}$ and the cross-sectional surface of the grooves for rolling $A_{1}$ were determined with respect to the nominal diameter of the SD, the core diameter and the angle of rise of the spiral, provided that the groove: key ratio is $1: 1$. For the grinding procedure, the diameter and core thickness were set according to the SD producer's technology charts, and the rolling operation was expected to provide a grinding additive of $0.5 \mathrm{~mm}$ for SD $\varnothing 12,0.55 \mathrm{~mm}$ for SD $\varnothing 15$ and $0.75 \mathrm{~mm}$ for SD $\varnothing 20 \mathrm{~mm}$. For both operations, an angle of rise of $27^{+/-2}$ of the grooves was adopted. According to A. K. Dell et al. ${ }^{13}$ and L. F. Xavier et al. ${ }^{14}$, the best geometry of a SD depends on the property of the drilling material, and for the drilling of steel

\begin{tabular}{|c|c|c|c|c|c|c|}
\hline \multirow{2}{*}{$\begin{array}{l}\text { Nominal diameter } \\
\text { of SD }\end{array}$} & \multicolumn{3}{|c|}{ Rolling operation } & \multicolumn{3}{|c|}{ Grinding operation } \\
\hline & Core diameter & Core thickening & $\begin{array}{c}\text { Angle of rise of } \\
\text { spiral }\end{array}$ & Core diameter & Core thickening & $\begin{array}{c}\text { Angle of rise of } \\
\text { spiral }\end{array}$ \\
\hline$\emptyset 12$ & 3.0 & $0.96-1.20$ & \multirow{3}{*}{$27^{+1-2 \circ}$} & 2.0 & $0.96-1.20$ & \multirow{3}{*}{$27^{+/-2 \circ}$} \\
\hline$\varnothing 15$ & 3.4 & $1.20-1.50$ & & 2.38 & $1.20-1.50$ & \\
\hline$\varnothing 20$ & 4.0 & $1.40-1.75$ & & 3.0 & $1.40-1.75$ & \\
\hline
\end{tabular}
and cast iron, they propose an angle of rise of $24-32^{\circ}$.

Table 2: Dimensions of the SD groove according to the new technological procedure 
The data for the SD nominal diameters of $(\varnothing 12, \varnothing 15$ and Ø20) $\mathrm{mm}$ are shown in Table 2.

Based on the dimensions of the SD groove, Table 2, provided that the groove and the key width were in a ratio of 1:1, and after the sharpening operation at a top angle of $118^{\circ}$, the cutting edge was a straight line, generating a geometric model of a SD in the AutoCAD application program. The surface of the grinding additive $A_{2}$ and the SD groove surface were measured in the SD cross-section for rolling and grinding. The obtained values are shown in Table 3.

Table 3: Dimensions of the SD groove for rolling and grinding

\begin{tabular}{|c|c|c|c|}
\hline \multirow{2}{*}{$\begin{array}{l}\text { Nominal } \\
\text { diameter } \\
D(\mathrm{~mm})\end{array}$} & \multirow{2}{*}{\begin{tabular}{|c} 
Rolling oper- \\
ation
\end{tabular}} & \multicolumn{2}{|c|}{ Grinding operation } \\
\hline & & $\begin{array}{c}\text { Groove sur- } \\
\text { face } \\
A_{1}+A_{2}\left(\mathrm{~mm}^{2}\right)\end{array}$ & $\begin{array}{c}\text { Surface of grinding } \\
\text { additive } \\
A_{2}\left(\mathrm{~mm}^{2}\right)\end{array}$ \\
\hline$\varnothing 12$ & 45.26 & 55.94 & 10.68 \\
\hline$\varnothing 15$ & 73.24 & 88.05 & 14.81 \\
\hline$\varnothing 20$ & 130.72 & 157.78 & 27.06 \\
\hline
\end{tabular}

The difference in the length of the raw part of the SD grooves made with the new technological process with respect to the rolling technology is the length of the SD body made from the grinding additive $x$ for the SDs with the nominal diameters of $(\varnothing 12, \varnothing 15$ and $\varnothing 20) \mathrm{mm}$, as shown in Table 4.

Table 4: Calculation of the difference in the length of the raw part

\begin{tabular}{|l|c|c|c|}
\hline \multicolumn{1}{|c|}{ Nominal diameter of SD } & $\varnothing 12$ & $\varnothing 15$ & $\varnothing 20$ \\
\hline $\begin{array}{l}\text { Length of the raw part at which } \\
\text { the grooves are rolled } l_{\mathrm{s}}(\mathrm{mm})\end{array}$ & 55 & 60 & 79 \\
\hline $\begin{array}{l}\text { Cross-sectional surface of the } \\
\text { grinding additive } A_{2}\left(\mathrm{~mm}^{2}\right)\end{array}$ & 10.68 & 14.81 & 27.06 \\
\hline $\begin{array}{l}\text { Cross-section of the raw part } A \\
\left(\mathrm{~mm}^{2}\right)\end{array}$ & 113.04 & 176.63 & 314.00 \\
\hline $\begin{array}{l}\text { Cross-sectional surface of } 2 \\
\text { grooves } A_{1}\left(\mathrm{~mm}^{2}\right)\end{array}$ & 45.26 & 73.24 & 130.72 \\
\hline $\begin{array}{l}\text { Difference in the raw-part length } \\
x(\mathrm{~mm})\end{array}$ & 8.67 & 8.60 & 11.66 \\
\hline
\end{tabular}

The difference in the length of the raw part used for making SD grooves with the new technological procedure compared to the SD grooves made with the rolling process and the length of the raw part for making SD grooves with the rolling process represents the length of the raw part for making SD grooves with the new technological process. Calculated in that way, the dimensions of the raw parts for the production of SDs with nominal diameters of $(\varnothing 12, \varnothing 15$ and $\varnothing 20) \mathrm{mm}$ are shown in Table 5 .

Table 5: Dimensions of the raw part and savings of the material for the production of SDs with the new technological process

\begin{tabular}{|c|c|c|c|c|}
\hline \multirow{2}{*}{$\begin{array}{c}\text { Nominal di- } \\
\text { ameter of } \\
\text { SD }\end{array}$} & \multicolumn{2}{|c|}{ Length of the raw part (mm) } & $\begin{array}{c}\text { Material } \\
\text { savings }\end{array}$ \\
\cline { 2 - 5 } & $\begin{array}{c}\text { New tech- } \\
\text { nological } \\
\text { process }\end{array}$ & $\begin{array}{c}\text { Grinding } \\
\text { process }\end{array}$ & $(\mathrm{kg})$ & $(8 \%)$ \\
\hline$\varnothing 12$ & 113 & 151 & 35.43 & 25 \\
\hline$\varnothing 15$ & 123 & 169 & 66.36 & 27 \\
\hline$\varnothing 20$ & 155 & 205 & 126.97 & 24 \\
\hline
\end{tabular}

\subsection{Economic analysis of the new technological pro- cess of producing SD grooves with respect to grind- ing-wheel savings}

By making SD grooves with the new technological process, in comparison to making SD grooves with the grinding technology, in addition to material savings, a saving in the grinding wheel is achieved, which is proportional to the amount of the material removed during the grinding operation. Figure 3 shows the cross-sectional surfaces of the SD grooves made with the grinding technology $\left(A_{1}+A_{2}\right)$ as well as the cross-sectional surface of the grinding additive, removed after the rolling within the new technological process for making SD grooves.

A comparative analysis of the volume of the material removed during the formation of grooves with the SD grinding technology and the new technological procedure is given in Table 6.

\section{CONCLUSION}

The new SD-groove production technology is a combination of two processes: rolling and grinding. The rolling process is performed with a grinding additive. This additive is removed during the grinding process. SDs with grooves produced with this method retain all the advantages of the grooves produced by rolling and the

Table 6: Comparative analysis of the volume of the material taken off when making grooves with the SD grinding technology and the new technological process

\begin{tabular}{|c|c|c|c|c|c|c|c|c|}
\hline \multirow[b]{2}{*}{$\begin{array}{l}\text { Nominal } \\
\text { diameter }\end{array}$} & \multicolumn{3}{|c|}{ Grinding operation } & \multicolumn{3}{|c|}{ New operation } & \multirow[b]{2}{*}{$\begin{array}{c}\text { Difference in } \\
\text { the volume } \\
\text { of the cutting } \\
\text { material } \\
l_{1} \cdot A_{1}\left(\mathrm{~mm}^{3}\right)\end{array}$} & \multirow[b]{2}{*}{$\begin{array}{c}\text { Relative } \\
\text { savings } \\
(\%)\end{array}$} \\
\hline & $\begin{array}{c}\text { Surface of } \\
\text { the groove } \\
A_{1}+A_{2}\left(\mathrm{~mm}^{2}\right)\end{array}$ & $\begin{array}{l}\text { Length of } \\
\text { the spiral } \\
l_{1}(\mathrm{~mm})\end{array}$ & $\begin{array}{l}\text { Volume of } \\
\text { the cutting } \\
\text { material } \\
l_{1} \cdot\left(A_{1}+A_{2}\right) \\
\left(\mathrm{mm}^{3}\right)\end{array}$ & $\begin{array}{l}\text { Surface of } \\
\text { the grinding } \\
\text { additive } \\
A_{2}\left(\mathrm{~mm}^{2}\right)\end{array}$ & $\begin{array}{l}\text { Length of } \\
\text { the spiral } \\
l_{1}(\mathrm{~mm})\end{array}$ & $\begin{array}{c}\text { Volume of } \\
\text { the cutting } \\
\text { material } \\
l_{1} \cdot A_{2} \\
\left(\mathrm{~mm}^{3}\right)\end{array}$ & & \\
\hline$\varnothing 12$ & 55.94 & 102 & 5705.88 & 10.68 & 102 & 1089.36 & 4616.52 & 80.91 \\
\hline$\varnothing 15$ & 88.05 & 115 & 10127.75 & 14.81 & 115 & 1703.15 & 8424.60 & 83.18 \\
\hline$\varnothing 20$ & 157.78 & 141 & 22246.98 & 27.06 & 141 & 3815.46 & 18431.52 & 82.85 \\
\hline
\end{tabular}


grooves produced by grinding while, at the same time, eliminating their disadvantages.

In addition, the conducted economic analysis showed that this technological process allows us to achieve material savings of 24-27\% and grinding-wheel savings of $82-83 \%$.

\section{Acknowledgment}

This paper is the result of a scientific research project "Making of grooves of spiral drills using a combination of rolling and grinding processes", funded by the Ministry of Science and Technology Development, Higher Education and Information Society of the Republic of Srpska.

\section{REFERENCES}

${ }^{1}$ T. Bulzak, Z. Pater, Numerical analysis of the extrusion process of twist drills, Acta Metallurgica Slovaca, 19 (2013) 2, 132-140, doi:10.12776/ams.v19i2.97

${ }^{2}$ T. Bulzak, J. Tomczak, Z. Pater, Method for producing twist drills by extrusion using a three-slide forging press, Key Engineering Materials, 622-623 (2014), 129-135

${ }^{3}$ W. Cubberly, R. Bakerjian, Tool and manufacturing engineers handbook, Desk edition, Society of Manufacturing Engineers, Chapter 24 Michigan 1989

${ }^{4}$ G. Meral, M. Sarikaya, M. Mia, H. Dilipak, U. Seker, M. Gupta Multi-objective optimization of surface roughness, thrust force, and torque produced by novel drill geometries using Taguchi-based GRA, The International Journal of Advanced Manufacturing Technology, 101 (2019), 1595-1610, doi:10.1007/s00170-018-3061-z
${ }^{5}$ A. Vijayaraghavan, Automated drill design software,http://citeseerx. ist.psu.edu/viewdoc/download?doi=10.1.1.120.2976\&rep=rep 1 \&type=pdf, 28. 04. 2020

${ }^{6}$ J. Jovanović, O. Spaić, Geometric modeling of twist drills, Proc. of the 16th International Research/Expert Conference "Trends in the Development of Machinery and Associated Technology", TMT Dubai 2012, 29-32

${ }^{7}$ B. Denkena, A. Lucas, E. Bassett, Effects of the cutting edge microgeometry on tool wear and its thermomechanical load, CIRP Annals - Manufacturing Technology, 60 (2011), 73-76, doi:10.1016/ j.cirp.2011.03.098

${ }^{8}$ E. Portillo, I. Cabanes, J. A. Sánchez, D. Orive, N. Ortega, M. Marcos, A case study of a flexible software tool in the drilling process, Proc. of the 1st IFAC Conference on Embedded Systems, Computational Intelligence and Telematics in Control - CESCIT, Germany 2012, 333-338

${ }^{9}$ Z. Botak, K. Pisačić, M. Horvat, D. Mađerić, The influence of drill point geometry of tool life, Tehnički glasnik, 12 (2018), 1-4, doi:10.31803/tg-20171121114508

${ }^{10}$ R. Ren, J. Ni, Analyses of drill flute and cutting angles, Int. Journal of Advanced Manufacturing Technology, 15 (1999), 546-553, doi:10.1007/s001700050100

${ }^{11}$ T. Bulzak, Z. Pater, J. Tomczak, New extrusion process for producing twist drills using split dies, Applied Computer Science, 13 (2017) 3, 55-63, doi:10.23743/acs-2017-21

${ }^{12}$ I. Trupković, Z. Botak, Influence of geometry of cutting edge to drill life, Tehnički glasnik, 8 (2014) 1, 59-63

${ }^{13}$ A. K. Dell, H. R. Todd, Manufacturing Processes Reference Guide, Industrial Press Inc. 1994, 43-48

${ }^{14}$ L. F. Xavier, D. Elangovan, Effective Parameters for Improving Deep Hole Drilling Process by Conventional Method - A Review, International Journal of Engineering Research \& Technology (IJERT), 2 (2013) 3, 01-11 